Ann. Biol. anim. Bioch. Biophys., 1977, 17 (1), 55-62.

\title{
Correlation between liver weight and blood serum biochemical parameters in force fed interspecific hybrid ducks
}

\author{
par J. CSUKA, Ludmila KINDLOVA, J. STASKO
}

Laboratory of Genetics, Poultry Research Institute 90028 Ivanka pri Dunaji, Czechoslovakia.

Summary. Interspecific hybrid ducks, obłained by crossing domestic with Muscovy, are crammed and compared to controls. Cramming causes significant differences in the blood serum GOT, GPT, cholesterol and amylase levels. Significant differences in the major parameters are also found between large-liver and small-liver animals and with high weight gain or low gain.

The following correlations are : liver size and GOT, $r=+0.583$; liver size and GPT, $r=+0.490$; liver size and cholesterol, $r=+0.324$. The correlation between relative gain during force feeding and GOT level is $r=+0.483$; between that gain and GPT it is $r=+0.421$.

\section{Introduction}

Because of the large demand for goose liver and its high price, interspecific hybrid ducks are used for large-liver production. These birds are crosses of Muscovy, Pekin and other domestic duck breeds; they are raised to a large extent in Japan, France and Hungary. Stasko (1973) reported on the production of these hybrids and their performance in Czechoslovakia.

There has been much work done in the last ten years on the physiological factors affecting liver development in goose. Structural alteration of hepatic tissue due to force feeding is summarized by Baldissera-Nordio (1974) and Trefny ef al, (1974). According to Blum et al. (1970), serum albumin level is closely correlated to liver size. Cornelius (1970) advances a similar opinion. Nir (1972) found a significant negative correlation between liver weight and serum protein $(r=-0.341)$ and serum albumin $(r=-0.543)$. Yaman ef al. (1973) reported that serum albumin increased during force feeding while the globulin decreased. 
Blum ef al. (1970), Baldissera-Nordio (1971) and Sova and Nemec (1972) observed a higher bilirubin level in the serum after force feeding. Sova ef al. (1971) reported that cholesterol augmented from 143 to $233 \mathrm{mg}$ as a result of force feeding. This rise was also observed by Blum et $a l$. (1970) and Baldissera-Nordio (1971). Niespodziewanski (1971) studying the effect on the liver of force feeding, recorded an increase in cholesterol, protein, hydrocarbon and red blood count values. Sevcikova ef al. (1974) found a decrease in $\alpha$-lipoprotein level from 60.9 and 62.8 p. 100 to 26.6 and 19.5 p. 100, respectively, during force feeding. A $\beta$-lipoprotein increase was noted.

Ivorec-Szylit and Szylit (1969) observed that plasma LDH (lactate dehydrogenase) level of geese, force fed for liver production, rose from day 5 to day 8 of force feeding. If then dropped in all birds with positive steatosis. Losonczy (1970) and Link and Losonczy (1971) reported that geese with a lower amylase level at the end of force feeding had fatter (larger) livers. These authors believed this result could be used as an index of optimum slaughter time; geese slaughtered when amylase level was minimum had a 30 p. 100 heavier liver than the controls.

Leclercq and Blum (1971) in three force feeding experiments on geese, noted variations in blood serum GOT (glutamate oxalacetate transaminase), GPT (glutamate pyruvate transaminase) and LDH levels. They observed significant positive correlation between GOT and GPT levels and liver weight at the end of the experiments, and a slight correlation between GPT and liver weight.

In this report, we study some biochemical indicators of liver steatosis in interspecific hybrid ducks to determine if these indices can be used to estimate liver size.

\section{Material and methods.}

Five combinations ( 3 males and 3 females each) of interspecific hybrid ducks were used in this experiment. Muscovy drakes were mated with Small broiler duck, Pekin, Campbell and with interbred hybrids Campbell $\times$ Small broiler duck and Small broiler duck $\times$ Campbell.

The Alsace force feeding method was employed; birds were crammed twice daily with steamed maize for 21 days. The animals were 142 days old at the end of the force feeding. Feed comsumption was $6-7 \mathrm{~kg} / \mathrm{kg}$ of body weight gain and $22-28 \mathrm{~kg} / \mathrm{kg}$ of liver produced.

Live weight was ascertained at the beginning of force feeding and a $10 \mathrm{ml}$ blood sample was drawn from the wing vein. At the end of force feeding live weight was noted ; true body gain was expressed in $\mathrm{kg}$ and relative body gain as a percentage of the initial weight. A blood sample was taken for a second time after fattening. Five birds died during force feeding. They were replaced by animals of the same combination, the fattening test being carried out with a larger number of birds. Thus, the correlation between biochemical markers determined at the beginning of fattening and the performance of birds at the end of the period is not evaluated in this study.

GOT and GPT levels were measured using the Biotest from Labora Brno (Reitman and Frankel, 1957). Cholesterol level was determined by Watson's method (1960). Blood serum refraction was measured at $20^{\circ} \mathrm{C}$ with an Abbe model refractometer. Total sugar content was determined using Smith and Roe's Antron method (1949). 


\section{Results.}

Biochemical variation due to force feeding.

There was no significant difference in the refractometric values of serum proteins and lipids in the force fed and control animals. Total sugar content was similar in the two groups, while there was high individual variability within the groups. Force feeding increased blood cholesterol from 219.8 to $339.6 \mathrm{mg}$ (54 p. 100 increase). Individual variability of this character was rather low, particularly in the controls. However, we found a highly significant difference in serum cholesterol between force fed and control ducks.

The most evident variations caused by force feeding were noted in the transaminases. Before force feeding GOT level usually reached $0.784 \mu \mathrm{mol}$; after four weeks of force feeding it increased to $3.45 \mu \mathrm{mol}$ ( $30 \mathrm{p}$. 100 increase). This difference in enzyme level prior to and at the end of fattening is highly significant (table 1). Individual

\section{TABLE 1}

Marker traits in force fed and control ducks

\begin{tabular}{|c|c|c|c|c|c|c|c|c|}
\hline \multirow[b]{2}{*}{$\begin{array}{l}\text { Physiological } \\
\text { state }\end{array}$} & \multicolumn{8}{|c|}{ Marker traits } \\
\hline & $\begin{array}{l}\text { Refrac- } \\
\text { tion }\end{array}$ & $\begin{array}{c}\text { Total } \\
\text { sugar } \\
\mathrm{mg} / 100 \mathrm{ml} \\
\text { of serum }\end{array}$ & $\begin{array}{c}\begin{array}{c}\text { Choles- } \\
\text { terol } \\
\mathrm{mg} / 100 \mathrm{ml} \\
\text { of serum }\end{array}\end{array}$ & $\begin{array}{c}\text { GOT } \\
\mu \mathrm{mol} / \mathrm{ml} \\
\text { of serum }\end{array}$ & $\begin{array}{c}\text { GPT } \\
\mu \mathrm{mol} / \mathrm{ml} \\
\text { of serum }\end{array}$ & $\begin{array}{l}\text { Amylase } \\
\text { units } / \mathrm{ml} \\
\text { of serum }\end{array}$ & $\begin{array}{c}\text { Liver } \\
\text { weight } \\
g\end{array}$ & $\begin{array}{c}\text { Relative } \\
\text { gain } \\
\text { p. } 100\end{array}$ \\
\hline \begin{tabular}{l|l} 
Prior to force & $\overline{\mathbf{x}}_{1}$ \\
feeding $\ldots \ldots$ & $s_{1}$
\end{tabular} & $\begin{array}{l}1.3445 \\
0.22\end{array}$ & $\begin{array}{r}150.0 \\
82.0\end{array}$ & $\begin{array}{r}219.8 \\
38.2\end{array}$ & $\begin{array}{l}0.784 \\
0.423\end{array}$ & $\begin{array}{l}0.532 \\
0.370\end{array}$ & $\begin{array}{l}35.16 \\
12.20\end{array}$ & - & - \\
\hline \begin{tabular}{l|l} 
At the end of & $\bar{x}_{2}$ \\
force feeding & $s_{2}$
\end{tabular} & $\begin{array}{l}1.3447 \\
0.20\end{array}$ & $\begin{array}{r}152.0 \\
74.0\end{array}$ & $\begin{array}{r}339.6 \\
85.5\end{array}$ & $\begin{array}{l}3.450 \\
1.760\end{array}$ & $\begin{array}{l}2.950 \\
1.610\end{array}$ & $\begin{array}{r}44.80 \\
9.49\end{array}$ & $\begin{array}{l}297.2 \\
149.0\end{array}$ & $\begin{array}{l}52.7 \\
16.6\end{array}$ \\
\hline Difference $\bar{x}_{1}-\bar{x}_{2}$ & - & - & 54 & 340 & 454 & 27 & $\begin{array}{r}* \dagger 0.0 \\
* * \dagger 0.0 \\
N=28\end{array}$ & $\begin{array}{l}5=2.05 \\
1=2.76 \\
8\end{array}$ \\
\hline $\begin{array}{l}\text { Significance of the } \\
\text { difference ..... }\end{array}$ & 0.058 & 0.66 & $8.55^{* *}$ & $8.69 * *$ & $8.45^{* *}$ & $6.93 * *$ & $* *=\mathrm{hi}$ & $\begin{array}{l}\text { igly } \\
\text { gnificant }\end{array}$ \\
\hline
\end{tabular}

variability of the character was also high prior to fattening and thus at the end of the period. GPT level reached $0.532 \mu \mathrm{mol}$ in the controls and $2.95 \mu \mathrm{mol}$ in the force fed ; this represents a 454 p. 100 increase. The difference between the levels prior to and at the end of force feeding is highly significant. The variability of this enzyme activity is higher than that of GOT before and after fattening.

Amylase content only increased from 35.16 to 44.80 units $(27$ p. 100$)$ due to iorce feeding. However, this difference is highly significant. Individual amylase variability was low in force fed birds while it was mean in the controls. 
Liver weight and biochemical parameters.

The force fed ducks were divided into two groups of 15 birds each according to liver weight which ranged from $75 \mathrm{~g}$ to $575 \mathrm{~g}$. Mean liver weight in beffer force fed ducks was $421.3 \mathrm{~g}$ while in the poorer animals it was $173.1 \mathrm{~g}$. Mean liver weight of the 30 force fed ducks was $297.2 \mathrm{~g}$.

We also whished to see if liver size affected the biochemical parameters used for determining the degree of liver fatness. Duck liver size appeared to be correlated to serum refraction, total sugar content and amylase (table 2). Differences in blood

TABLE 2

Correlation between biochemical traits and liver size

\begin{tabular}{|c|c|c|c|c|c|c|c|}
\hline \multirow[b]{2}{*}{ Group } & \multicolumn{7}{|c|}{ Marker traits } \\
\hline & $\begin{array}{c}\text { Liver } \\
\text { weight } \\
g\end{array}$ & $\begin{array}{l}\text { Refrac- } \\
\text { tion }\end{array}$ & $\begin{array}{c}\text { Total } \\
\text { sugar } \\
\mathrm{mg} / 100 \mathrm{ml} \\
\text { of serum }\end{array}$ & \begin{tabular}{|c|} 
Choles- \\
terol \\
$\mathrm{mg} / 100 \mathrm{ml}$ \\
of serum
\end{tabular} \mid & $\begin{array}{c}\text { GOT } \\
\mu \mathrm{mol} / \mathrm{ml} \\
\text { of serum }\end{array}$ & $\begin{array}{c}\text { GPT } \\
\mu \mathrm{mol} / \mathrm{ml} \\
\text { of serum }\end{array}$ & $\begin{array}{l}\text { Amylase } \\
\text { units } / m l \\
\text { of serum }\end{array}$ \\
\hline 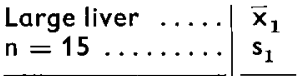 & $\begin{array}{r}421.3 \\
81.6\end{array}$ & $\begin{array}{l}1.3448 \\
0.203\end{array}$ & $\begin{array}{c}152.0 \\
81\end{array}$ & $\begin{array}{r}375.3 \\
61.8\end{array}$ & $\begin{array}{l}4,64 \\
1.51\end{array}$ & $\begin{array}{l}3.85 \\
1.41\end{array}$ & $\begin{array}{l}44.88 \\
11.20\end{array}$ \\
\hline 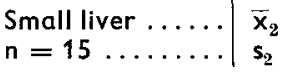 & $\begin{array}{r}173.1 \\
81.6\end{array}$ & $\begin{array}{l}1.3445 \\
0.202\end{array}$ & $\begin{array}{r}154.0 \\
66.0\end{array}$ & $\begin{array}{r}303.9 \\
93.8\end{array}$ & $\begin{array}{l}2.25 \\
0.94\end{array}$ & $\begin{array}{l}2.05 \\
1.28\end{array}$ & $\begin{array}{r}44.68 \\
7.82\end{array}$ \\
\hline $\begin{aligned} & \text { Difference } \bar{x}_{1}-\bar{x}_{2} \text { in } \\
& \text { per cent } \ldots \ldots \ldots \ldots\end{aligned}$ & 143 & - & - & 23.3 & 106 & 87 & - \\
\hline $\begin{array}{l}\text { Significance of the diffe- } \\
\text { rence } \ldots \ldots \ldots \ldots \ldots\end{array}$ & $4.03 * *$ & 0.06 & 1.00 & $3.91 * *$ & $7.76 * *$ & $11.7 * *$ & 0.09 \\
\hline
\end{tabular}

cholesterol were relatively lower $(303.9 \mathrm{mg}$ and $375.3 \mathrm{mg}$ ), but significant (23.3 p. 100). GOT level in ducks with smaller livers reached $2.25 \mu \mathrm{mol}$, while it was $4.64 \mu \mathrm{mol}$ in ducks with larger livers (16 p. 100 increase). Thus, the difference between the largeliver and small-liver groups is highly significant. GPT level in the latter group reached $2.05 \mu \mathrm{mol}$ while in the former it was $3.85 \mu \mathrm{mol}$. This constitutes an $87 \mathrm{p} .100$ increase and is also highly significant.

Body weight gain and biochemical parameters.

The mean gain in force fed ducks was 52.7 p. 100, ranging from 25.8 to 92.3 p. 100 . Birds were divided into two groups according to weight gain, a high-gain group (mean 65.47 p. 100) and a low-gain group (mean 39.90 p. 100). These groups were significantly different.

There was no significant difference between the two groups as to blood serum refraction, total sugar level or amylase. The difference in serum cholesterol was relatively slight $(325.4 \mathrm{mg}$ and $353.8 \mathrm{mg}$ ); it is statistically non-significant. Serum cholesterol showed only a 8.9 p. 100 gain in the high-gain group. The low-gain 
group had a GOT level of $2.62 \mu \mathrm{mol}$ and the high-gain group $4.26 \mu \mathrm{mol}$. The difference $(62.2$ p. 100$)$ is highly significant (table 3$)$. GPT level in the low-gain group was $2.18 \mu \mathrm{mol}$ while it was $3.73 \mu \mathrm{mol}$ in the high-gain group. This difference $(70.6$ p. 100) is highly significant.

TABLE 3

Correlation between biochemical traits and weight gain

\begin{tabular}{|c|c|c|c|c|c|c|c|}
\hline \multirow[b]{2}{*}{ Group } & \multicolumn{7}{|c|}{ Marker traits } \\
\hline & $\begin{array}{c}\text { Relative } \\
\text { gain } \\
\text { p. } 100\end{array}$ & $\begin{array}{l}\text { Refrac- } \\
\text { tion }\end{array}$ & $\begin{array}{c}\text { Total } \\
\text { sugar } \\
\mathrm{mg} / 100 \mathrm{ml} \\
\text { of serum }\end{array}$ & $\begin{array}{c}\text { Choles- } \\
\text { terol } \\
\mathrm{mg} / 100 \mathrm{ml} \\
\text { of serum }\end{array}$ & $\begin{array}{c}\text { GOT } \\
\mu \mathrm{mol} / \mathrm{ml} \\
\text { serum }\end{array}$ & $\begin{array}{c}\text { GPT } \\
\mu \mathrm{mol} / \mathrm{ml} \\
\text { serum }\end{array}$ & $\begin{array}{l}\text { Amylase } \\
\text { units } / \mathrm{ml} \\
\text { of serum }\end{array}$ \\
\hline $\begin{array}{l}\text { High weight gain } \ldots \mid \bar{x}_{1} \\
n=15 \ldots \ldots \ldots \ldots\end{array}$ & $\begin{array}{l}65.47 \\
11.44\end{array}$ & $\begin{array}{l}1.3444 \\
0.157\end{array}$ & $\begin{array}{r}156.0 \\
75,0\end{array}$ & $\begin{array}{r}353.8 \\
58.9\end{array}$ & $\begin{array}{l}4.26 \\
1.63\end{array}$ & $\begin{array}{l}3.72 \\
1.50\end{array}$ & $\begin{array}{l}44.93 \\
11.27\end{array}$ \\
\hline \begin{tabular}{l|l|} 
Low weight gain $\ldots$ & $\overline{x_{2}}$ \\
$n=15 \ldots \ldots \ldots \ldots$ & $s_{2}$
\end{tabular} & $\begin{array}{r}39.90 \\
9.11\end{array}$ & $\begin{array}{l}1.3449 \\
0.213\end{array}$ & $\begin{array}{r}148.0 \\
76.0\end{array}$ & $\begin{array}{l}325.4 \\
109.5\end{array}$ & $\begin{array}{l}2.62 \\
1.47\end{array}$ & $\begin{array}{l}2.18 \\
1.40\end{array}$ & $\begin{array}{r}44.63 \\
7.74\end{array}$ \\
\hline $\begin{array}{r}\text { Difference } \bar{x}_{1}-\bar{x}_{2} \text { in per } \\
\text { cent } \ldots \ldots \ldots \ldots \ldots \ldots\end{array}$ & 18.0 & - & - & 8.9 & 62.6 & 70.6 & - \\
\hline $\begin{array}{l}\text { Significance of the diffe- } \\
\text { rence } \ldots \ldots \ldots \ldots \ldots \ldots\end{array}$ & $14.3 * *$ & 0.04 & 1.40 & 1.19 & $8.63 * *$ & $10.6 * *$ & 0.13 \\
\hline
\end{tabular}

\section{Correlations between traits studied (table 4).}

Since some biochemical blood serum components increased during force feeding and there was a significant difference in some biochemical traits in high and low per-

TABLE 4

Phenotypic correlation belween steatosis markers and performance characteristics

\begin{tabular}{|c|c|c|c|c|c|c|}
\hline \multirow{3}{*}{ Performance characteristic } & \multicolumn{6}{|c|}{ Markers } \\
\hline & \multirow{2}{*}{ GOT } & \multirow{2}{*}{ GPT } & \multirow{2}{*}{ Cholesterol } & \multirow{2}{*}{ Amylase } & \multicolumn{2}{|c|}{ Weigth gain } \\
\hline & & & & & Relative & True \\
\hline Liver $\ldots \ldots \ldots \ldots \ldots \ldots$ & $+0.583 * *$ & $+0.490 * *$ & +0.324 & +0.116 & $+0.542 * *$ & $+0.525^{* *}$ \\
\hline Relative weight gain $\ldots \ldots \ldots \ldots$ & $+0.483^{* *}$ & $+0.421 *$ & +0.080 & +0.205 & - & - \\
\hline
\end{tabular}

formance birds, we compuled the correlation between the traits to determine if they would be useful selection criteria. Calculating the correlation between liver size on one hand, and relative $(r=+0,542)$ and true $(r=+0.525)$ body weight gain on the 
other, we concluded that relative weight gain is a more reliable marker for estimating liver steatosis.

There was a fairly high correlation $(r=+0.583)$ between liver weight and GOT. Correlation between liver weight and GPT was mean $(r=+0.490)$; between liver weight and cholesterol level it was lower $(r=+0.324)$, but still fairly evident. Using one character (GOT, GPT or cholesterol level) for selection, we succeeded in choosing the 12 best ducks from the 15 better birds. The correlation between relative weight gain and liver size was $r=+0,542$ and it ranks second to GOT.

There is also evident but lower correlation between body weight gain and the markers studied. The highest correlation was found between relative gain and GOT level $(r=+0.483)$, followed by GPT $(r=+0.421)$ and amylase $(r=+0.205)$; the correlation between weight gain and cholesterol is practically negligible $(r=+0.080)$.

\section{Discussion.}

Results obtained using biochemical markers to study steatosis in interspecific hybrid ducks are comparable to those obtained in geese. There was no idifference in blood sugar between force fed and control ducks. This result does not agree with those of Niespodziewanski (1971) who found an increase in serum sugar of goose. The most surprising find is that blood serum refraction in force fed and control ducks is not different despite the large discrepancies seen in the sera with the naked eye. Blood serum refraction expresses the protein and sugar levels and the alteration of some components due to steatosis may be balanced by increasing or decreasing other components. Decreased albumin and total protein levels are probably balanced by cholesterol increase, as indicated by Nir (1972). This highly significant increase due to force feeding corresponds to results obtained by other authors cifed (Blum et al., 1970 ; Baldissera-Nordio, 1971 ; Sova et al., 1971), except that the level is generally higher in geese (Sova ef al., 1971). The highly significant differences in GOT and GPT level in force fed and control ducks agree with the results of Leclercq and Blum(1971).

The percentage of blood amylase increase found does not agree with the results of Losonczy (1970) and Link and Losonczy (1971), who report a decrease in serum amylase after force feeding geese. However, our findings do confirm those of Forenbacher (1969) who reported an increase in amylase and lipase levels from week 1 of force feeding. At the end of week 3 these levels stabilized or increased.

There is close correlation between cholesterol, GOT and GPT levels and liver size in ducks in our experiment. The difference in amylase is not significant. Only GOT and GPT levels seem to be correlated with body weight gain ; differences in cholesterol and amylase levels are non-significant.

The correlation between weight gain during force feeding and liver size at the end of force feeding is high $(r=+0.542)$. This confirms the results of Bögre (1959) who reported a correlation of $r=+0.5$ between goose weight gain and liver weight, and those of NIR (1972) who found that $r=+0.597$. The low mean correlation between liver size and serum cholesterol $(r=+0.324)$ cannot be compared to other results or to geese because it has not yet been studied. However, it roughly 
corresponds to cholesterol increase due to force feeding. The correlations between liver weight and GOT and GPT activity observed in interspecific hybrid ducks are similar to the results of Leclercq and Blum (1971) studying goose. However, contrary to these authors, who found a low correlation between liver weight and GPT level, we noted a relatively higher correlation between these indicators.

Blood serum biochemical traits characterize the physiological distinctions between ducks before and after force feeding; these correlations resemble those in geese. Serum cholesterol, GOT and GPT levels in force-fed birds are reliable criteria for determining liver steatosis, and, to a lesser degree, for characterizing subcutaneous and inner fat deposits.

Accepté en juillet 1976.

Résumé. Chez des canards obtenus par croisement de races domestiques et moscoviłes, le gavage entraîne des différences significatives dans la teneur du sérum en GOT, GPT, cholestérol et amylase, par rapport aux animaux fémoins. Pour les paramètres principaux, on observe également des différences significatives selon que les canards ont un petit ou un gros foie et ont pris plus ou moins de poids.

Les corrélations observées sont les suivantes : poids du foie et GOT : $r=+0,583$; poids du foie et GPT : $r=+0,490$; poids du foie et cholestérol : $r=+0,324$; gain de poids relatif pendant le gavage et GOT $: r=+0,483$; gain de poids et GPT : $r=+0,421$.

\section{References}

BALDISSERA-NORDIO C., 1971. L'allevamento familiare ed industrialle delle oche e delle anatre e sur possibilita di espansione. Giorn. Avic. Veresine, 18, 121.

BALDISSERA-NORDIO C., 1974. Untersuchungen über die Qualität des Fettlebers von mit Mais zwangshyperernährten Gänsen und Enten. Sympozium o vyzive a metabolismu jater hus. Praha, 1974, 25-49.

BLUM J. C., GUAMETON J. C., MUH J. P., LECLERCQ B., 1970. Modification de la valeur des normes sanguines en fonction du degré de stéatose hépatique chez l'oie gavée. Ann. Rech. vétér., 1, 167-178.

BOGRE J., 1959. The relationship between the weight gain and liver production during fattening of geese (in Hungarian). Baromfiipar, 6, 2-3.

CORNELIUS C. E., 1970. Liver function. In KANEKO J. J., CORNELIUS C. E., Clinical biochemistry of domestic animals, second ed., Acad. Press, N. Y., London.

DELPHIA J. M., SINGH S., BASKIN H., 1967. The relationship of hyperthermia to liver growth and liver glycogen in the chick embryo. Poultry Sci., 46, 1454.

FORENBACHER S., 1969. Changements dans la composition du foie et du sang des oies au cours du gavage. Aliment et Vie, 57, 136.

IVOREC-SZYLIT O., SZYLIT M., 1969. Etude des lacticodéshydrogénases plasmatique et hépatique chez l'oie au cours d'une stéatose provoquée par gavage. Ann. Biol. anim. Bioch. Biophys., 9, 205-218.

LECLERCQ B., BLUM J. C., 1971. De l'évolution de quelques enzymes sériques au cours du gavage de l'oie ef de leur corrélation avec le poids du foie gras finalement obtenu. Ann. Biol. anim. Bioch. Biophys., 11, 225-231.

LINK E., LOSONCZY S., 1971. Serum amylase activity level as an indicator of liver metabolism. Int. Symp. Feed. Hyg. Goose, Hungary, 111. 
LOSONCZY M., BOGRE J., TAKACS E., LOSONCZY S., 1970. A new point of view of selection in goose. Relationships between the time of fattening and serum amylase activity (in Hungarian). Magyar Allatorvosok Lapja, 25, 105-108.

NIESPODZIEWANSKI M., 1971. Cholesterol, its fractions and total protein levels in serum, level of glucose in blood and hematocrit value of geese crammed for fatty livers (in Czecho-Slovak). Roczn. Nauk. Roln., Ser. B, 93, 265.

NIR I., 1972. Modifications of blood plasma components as related to the degree of hepatic steastosis in the forced-fed goose. Poultry Sci., 51, 2044-2049.

SMITH B. W., ROE J. H., 1949. J. Biol. Chem., 179, 53, Cited by HOREJSI J. ef al. 1956, Bilkoviny krevni plasmy SZN Praha.

SOVA Z., NEMEC Z., 1972. Free bilirubin and bilirubin monoglucuronid content in serum of four races of tchekoslovak geese (in Czecho-Slovak). CSSR. Vet. Med., Praha, 17, 469-474.

SOVA Z., VRBENSKA A., JICHA J., SEVCIKOVA I., TREFNY D., KOUDELA K., HOUSKA J., HOREJSI J., 1971. Total lipids, cholesterol, phospholipids and lipoproteins in sera of 4 races of geese reared in Tchekoslovakia (in Czecho-Slovak). CSSR. Sbornik VSZ Praha, PEF, C. Budejovice, Rada biologicka, 2, 548.

STASKO J., 1973. Problems of hybridization and insemination in geese breeding (in Czecho-Slovak). Vyrocna vedecka konferencia Ceskoslovenskej pobocky Svefovej hydinarskej vedeckej spolocnosti, Smolenice, 26-28 februara 1973, 90-108.

SEVCIKOVA I., VRBENSKA A., SOVA Z., TREFNY D., CIBULKA J., PETKOV S., VOLKOVA D., 1974. Serum lipoproteins in geese (in Czecho-Slovak). Veter. Med., 19, 313.

TREFNY D., BLAZEK K., SOVA Z., MIKULAS F., 1974. Biopsy of livers and their utilization in cramming of geese. (in Czecho-Slovak). Symposium o vyzive a mefabolismu jater hus. Praha, 1974, 125-126.

YAMAN K. A., MARA I. F. M., LOSONCZY S., 1973. Developmental changes in serum proteins, lipids and cholesterol during the course of force feeding in geese. Ann. Biol. anim. Bioch. Biophys., 13, 215-223. 